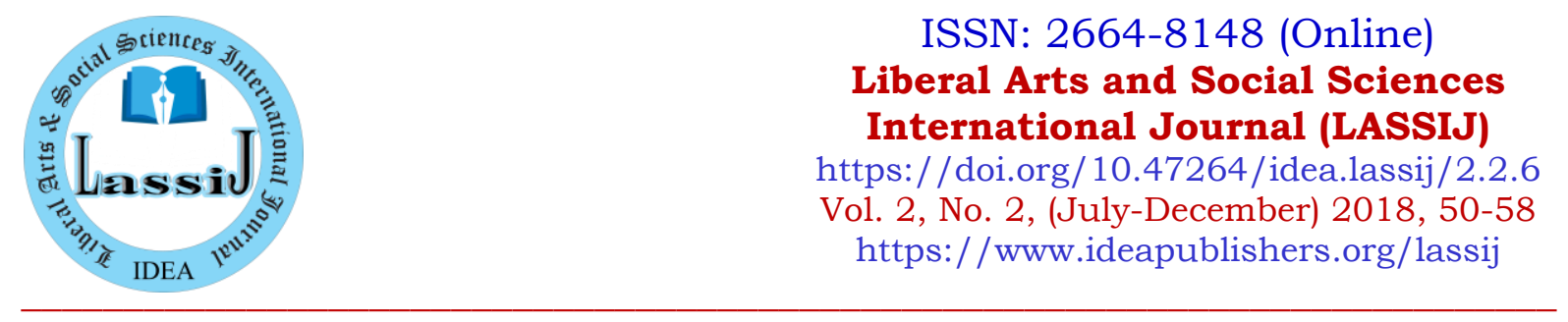

\title{
Gender Inequality in Education: An Analysis of Socio-Cultural Factors and Impacts on the Economic Development of Malakand, Pakistan
}

\author{
Umer Daraz $^{1}$, Akhlaq Ahmad ${ }^{2}$ and Muhammad Bilal ${ }^{3 *}$
}

1. Department of Sociology, University of Malakand, Chakdara Pakistan

2. Department of Sociology, International Islamic University, Islamabad Pakistan

3. Department of Sociology, Abdul Wali Khan University, Mardan Pakistan

\begin{abstract}
Women's education is the most effective channel for reducing the inequalities between men and women and ensuring the maximum participation of women in the developmental process. This study is conducted in Malakand Division of Khyber Pakhtunkhwa Pakistan. Further this Paper explains the socio-cultural reasons of gender inequality in education, and to investigate that how this inequality affects the economic stability. The data is collected through questionnaire from 165 household using cluster random sampling technique. Chi-square test and correlation technique are utilized for the verification of hypotheses which proves that the gender inequality in education is as an endogenous variable and show that it can be explained to a considerable extent by culturalreligious preference, and regional factors. It is concluded from the study that, gender disparity in education reduces human per capita income. The study suggests that to improve human development in the context of per capita production, women's education must be improved through the elimination of disparity in the text and by relaxing the socio-cultural factors.
\end{abstract}

Keywords: Gender, Inequality, Education, Socio-Cultural Impediments, Human Capital, Economic Stability

\section{Introduction}

Education as a sound instrument cannot be denied for humans over all development. It specifically improves socio-economic, political, and cultural capitals of human life and provides a unique orientation for human' survival. Intriguingly, education's role is highly instrumental in improving gender discourse and particularly women's empowerment. As a result, education-based women's empowerment generates good capitals for overall societal development because this process is incomplete without women's role. Women's education plays a paramount role especially in the economic development of the society (Chaudhry, 2010). However, unfortunately the unequal gender-based access to education in the developing countries has influenced their economic development. Although women constitute almost half of the population but still, they face barriers in getting equal education opportunities as compared to their male counter parts (Berhman, 1997). Several factors are affecting women's education and economic development subsequently. However, social, and cultural factors have significant impact in this process. 


\section{Theoretical Engagements in the Study}

An academically rich body of theoretical literature is available on the role of women's education and its contribution in the economic development. However, the current study fits into human capital approach as education itself is part of the cultural human capital. By human capital approach in this study, we meant that women's education has emerged as an important determinant of economic development and child mortality, having a stronger impact in many cases than income (Mensch, Lentzner, \& Preston, 1985; Schultz, 1993; Ullah, Mustafa, \& Badshah, 2017). Human capital approach suggests that women's education has a strong impact on per capita income of children's health and nutrition (Behrman \& Deolalikar, 1988; Behrman \& Wolfe, 1984; Strauss \& Thomas, 1995). As this study reveals that women's education is an important determinant of economic development as it increases GNP and GDP production, along with children's schooling. Besides, capabilities and education have strong impact on both the GDP and GNP growth (Schultz, 2002; Behrman, 1997; Montgomery, Arends-Kuenning, \& Mete, 2000).

As per human capital approach, women's education is valued because it is an effective instrument to achieve other outcomes, such as, economic production, high market out puts, human development and fertility decline. By arguing that women's education is a sound investment because educated mothers are more effective in reaching goals that society holds valuable than uneducated mothers, traditional roles are strengthened. Norms and practices that are harmful to women, such as dowry, are not questioned. Educational programs that do not seek to change norms might discriminate against girls and women. Education might increase women's abilities to make choices, but the choices are often constrained by norms and conditions that favour men over. Therefore, this approach is instrumentalist, viewing human capital as an input to production. Growth-oriented development economists advocate investments in women's education because it adds to human capital. Human capital is an input into a productive process, and enhancing human capital increases the commodities that a society can produce (Todaro, 1997). Increasing a society's educational level leads to the higher levels of economic growth because the educated people are more productive than the uneducated people.

Social factors like, women's unequal access to education, health, and recreational facilities in comparison to men, influence women's economic growth across different classes of the society. These are the major areas which discriminate women as social factor(s) and most importantly affecting economic development (Lagerlof, 2003; King \& Hill, 1993). Theorists in the field of economics suggest that education role is undeniable in the growth of per capita income but unfortunately half of the population (women) has always been ignored in this regard. They are of the opinion that women's education has a positive coefficient with the development of human capital (Yamarik \& Ghosh, 2003). Furthermore, some other studies reveal that women's education in the developing countries is closely associated with high economic productions as lower female education had negative impact on economic growth as it degrades the average level of human capital (i.e. female education reduces fertility, infant mortality, increases children's education and promotes economic output (Klasen, 2002; Knowles, Lorgelly, \& Owen, 2002). Besides, an amount of empirical studies find that increase in women's education boosts their wages and that returns to education for women are frequently larger than that of men and are very beneficial for sound market economy (King \& Hill, 2001; Schultz, 1997). Women's education has a prime role in women's empowerment and societal development that has a significant role in flourishing human capital and economic growth (Mishra, 2005). In 
developed countries there is equal education both for male and female therefore women enjoy high status, furthermore it has been proved that basic education of girls and women improves the key development outcomes, such as reducing fertility and child mortality or increasing work productivity and achieve capital goals (Ranynor \& Wesson, 2006).

Cultural discourses are also playing significant role in human's orientation especially in women's one because they have always been a neglected portion of the societal population in this regard. Discrimination with women population based on cultural stereotypes is seriously affecting economic development because with weak cultural capital they cannot compete men in all other spheres of life. Education in the cultural context enhances women's well-being and gives them a greater voice in household decisions, more autonomy in shaping their lives and better opportunities for participating in the community and labour market (Krueger \& Lindahl, 2000). Women education regarded as a key factor in overcoming all the barriers that women face in their empowerment. Education itself is an empowering tool both for male and female and a compulsory component of human organization and development, It is not only the source of getting knowledge and to improve skills, but is also enhances the mental horizon of male and female and decreases the dependency in health, livelihood and economy. Besides, it empowers women to take their rights place in society and development process gives them status and confidence in decision making and further it is the key to reducing poverty (Jejeebhoy, 1995; Cohen \& Soto, 2001). Gender equality in education improve the production of a country as both male and female equally took part in the countries development process and decrease the ratio of poverty (Hannan, 2004). As women education is related to the reduction of poverty and creates women bargaining power both in the family and at the community level likewise Sen (1990) elucidates that, education might encourage women's empowerment by increasing women's bargaining position within the household.

\section{Research Methodology}

This study is conducted under a positivist paradigm. The objectivist or realist ontology of this study considers socio-cultural factors behind gender inequality in education as objective reality and see its impact on economic development in the province of KP. Moreover, the stated gender inequality is approached through empiricist epistemology. The ontologically objectivist and epistemologically empiricist prescriptions of the positivist paradigm guide us for a quantitative method in this study which includes of different methods and procedures.

The locale of this study is Chakdara village, Tehsil Chakdara, District Dir (Lower), Malakand division Khyber Pakhtunkhwa. Through cluster random sampling method, different clusters are made in the village to meet the requirement of a field survey. Consequently, a sample of 165 households were selected randomly. A well-established questionnaire (consisting of two sections) for data collection is designed with both open ended and close ended questions. Section first of the questionnaire is focused on socio-economic status of the respondents (i.e. respondent's educational level, family size, family income, family type and age).However, second section of the questionnaire is related to gender disparity in text, student's enrolment etc. The collected data is passed on through quantitative data analysis technique. Univariate analysis is done with the help of descriptive statistics and socio-demographic features of the respondents are analysed through frequency distribution and mean. Besides, the bivariate analysis is done through the correlation and chi-square test of the inferential statistics. Through chi-square test, the level of significance between gender inequality in education and its association with the economic development is measured. 


\section{Analysis and Discussion}

The data has been statistically interpreted through statistical analysis such as Chi-square test and correlation with respect to the attainment of authenticity and accuracy and validity of hypotheses. In respect of more convenience of the results, the data has been passed through tabulation, explanation, and pictographic presentation in shape of bar charts at the end of each table to clarify the percentages. The tables comprise of various segments i.e. the 'categories' which has been mentioned in the tables and denoted in alphabetic and Figurative design for easy understanding and expediency of the readers such as $\mathrm{C} 1, \mathrm{C} 2, \mathrm{C} 3 \mathrm{etc}$, while at the bottom of each table the total frequencies and percentages have been denoted by CT. Category is followed by the 'variable' along-with its distribution having the 'frequencies', 'percentage'. The response of respondents is recorded on two points categories i.e., 'to lower extent' and 'to greater extent' abbreviated as (TLE) and (TGE) coded as 1 and 2 accordingly.

\subsection{Gender Disparity in Education and Women Education}

In Pakhtun's society gender inequality exists in various spheres of social life, especially at the educational sector the ratio of gender inequality is on peak, the data support the argument i.e., gender disparity in the educational sector are very much sever and caused women illiteracy, decrease the status of women and affect the overall literacy ratio of country. The discussion has been divides into ten categories denoted by $\mathrm{C} 1, \mathrm{C} 2, \mathrm{C} 3, \mathrm{C} 4, \mathrm{C} 5, \mathrm{C} 6, \mathrm{C} 7, \mathrm{C} 8, \mathrm{C} 9$ and $\mathrm{C} 10$.

Table-1: Cross Tabulation of Gender Disparity in Education and Women Education

\begin{tabular}{|c|c|c|c|c|}
\hline \multirow[b]{2}{*}{ Categories } & \multirow[b]{2}{*}{ Gender Disparity in Education } & \multicolumn{2}{|c|}{ Women Education } & \multirow[b]{2}{*}{ Total } \\
\hline & & $\begin{array}{c}\text { To Lower } \\
\text { Extent }\end{array}$ & $\begin{array}{c}\text { To Greater } \\
\text { Extent }\end{array}$ & \\
\hline $\mathrm{C} 1$ & Disparity in text & $0(0 \%)$ & $18(100 \%)$ & $18(100 \%)$ \\
\hline $\mathrm{C} 2$ & Disparity in educational enrolment & $0(0 \%)$ & $14(100 \%)$ & $14(100 \%)$ \\
\hline $\mathrm{C} 3$ & High drop out of female & $0(0 \%)$ & $20(100 \%)$ & $20(100 \%)$ \\
\hline $\mathrm{C} 4$ & Gender priorities & $0(0 \%)$ & $30(100 \%)$ & $30(100 \%)$ \\
\hline $\mathrm{C} 5$ & Social preference & $10(33 \%)$ & $20(67 \%)$ & $30(100 \%)$ \\
\hline C6 & High cost of education & $5(31 \%)$ & $11(69 \%)$ & $16(100 \%)$ \\
\hline $\mathrm{C} 7$ & Disparity in selection of subject & $0(0 \%)$ & $7(100 \%)$ & $7(100 \%)$ \\
\hline $\mathrm{C} 8$ & Lower return for girls schooling & $4(36 \%)$ & $7(64 \%)$ & $11(100 \%)$ \\
\hline C9 & Disparity in educational policies & $0(0 \%)$ & $8(100 \%)$ & $8(100 \%)$ \\
\hline $\mathrm{C} 10$ & Lack of infrastructure facilities & $0(0 \%)$ & $11(100 \%)$ & $11(100 \%)$ \\
\hline $\mathrm{CT}$ & Total & $19(12 \%)$ & $146(88 \%)$ & $165(100 \%)$ \\
\hline
\end{tabular}

$\mathrm{P}=0.000^{* *}<0.05$ and $\chi 2=40.852$

The statistical analysis in Table-1 illustrates that gender disparity in education adversely affect economic development and human capital. The gender disparity in education exist to lower extent (TLE) are favoured by a few respondents (12\%) and to greater extent are marginalized by majority of the respondents $(88 \%)$ who evidently enumerate that gender disparity in education reduced women economic output to the family and society as a whole. The statistical analysis further demonstrates that gender disparity in text (C1) attributed $18 \%$, While $\mathrm{C} 2$ as $14 \%$ respondents, similarly high dropout (C3) count as $20 \%$, in a same way $30 \%$ respondents marks C4. Beside 33\%:67\% respondents strongly suggested that social preference (C5) in the 
educational sectors (decides by family) generally reduced the status of women in family and society at large. However, in calculating the quantitative results of gender disparity in education, 31\%:69\% respondents recommended C6. Moreover in equality in selection of subject (C7) exist like 7\%, likewise 36\%:64\% respondents fit in C8, whereas disparity in educational policies (C9) count as $8 \%$ and at last $11 \%$ respondents strongly tick (C10), that lack of infrastructure facilities is the main cause to gender disparity in education.

Resultantly, the gender disparity in education is proposed in the hypothesis "Disparity in text and enrolment causes illiteracy among Pakhtun's women." Which has been judge by applying chi-square test where the value of $\mathrm{P}=0.000^{* * *}<0.05$, shows that the result is highly significant and there is strong association between gender disparity in education and women illiteracy. Further the correlation analysis confirms the result in a man that ${ }^{* *}$ Correlation is highly significant at the 0.01 level (2-tailed), $r(165)=0.956 ; p<0.01 . r^{2}=0.91$, since $91 \%$ of the variance is shared, the association is obviously a strong one, which conclude that gender disparity is like a parasite to women education (see Table-2).

Table-2: Correlation of Women Education and Gender Disparity in Education

\begin{tabular}{|l|c|c|c|}
\hline \multirow{2}{*}{ Women's Education } & Women Education & Gender Disparity in Education \\
\hline & Pearson Correlation & 1 & $0.956^{* *}$ \\
\cline { 2 - 4 } & Sig. (2-tailed) & & 0.000 \\
\cline { 2 - 4 } & $\mathrm{N}$ & 165 & 165 \\
\hline \multirow{3}{*}{$\begin{array}{l}\text { Gender Disparity in } \\
\text { Education }\end{array}$} & Pearson Correlation & $0.0956^{* *}$ & 1 \\
\cline { 2 - 4 } & Sig. (2-tailed) & 0.000 & 165 \\
\cline { 2 - 4 } & $\mathrm{N}$ & 165 & \\
\hline
\end{tabular}

${ }^{* *}$ Correlation is highly significant at the 0.01 level (2-tailed), $r(165)=0.956 ; p<.01 . r^{2}=0.91$, since $91 \%$ of the variance is shared, the association is obviously a strong one

\subsection{Relation between Socio-Cultural Impediments and Women Education}

The collected information shows the alliance between socio-cultural impediments and women education in Pakhtuns society. It has been further elucidated by the results that socio-cultural constraints reduce women education in Pakhtun society: although there is variation in the sense that the obstacles are to low extent (TLE) marked by few likewise (15\%) while these are to greater extent (TGE) marked by majority $(85 \%)$. The statistical analysis further expounds that cultural impediments like, patriarchy and male dominancy (C1) added 2\%:98\% in decreasing women education. Customary laws which do not allow women to go outside home attributed (22\%:78\%) in women education (C2). Pakhtuns codes of life such as Haya, Nang, Ghairat, etc., moulding the results likewise $(25 \%: 75 \%)$ C3. Similarly gender bias social structure, which ignores women in the context of education, resulted 30\%:70\% (C4), feudalistic nature of society where priority is given to the traditions and values oppose women education in a manner 20\%:80\% (C5), negative perception regarding purdah and veiling add (21\%:79\%) C6. The statistical analysis further enumerated that poverty is one of the potential barrier to women's education and contribute the result likewise 18\%:82\% belong to $\mathrm{C} 7$, because the people in the area cannot afford education of their children including daughter and son. The analysis further illustrates that the indicator like unemployment contributed in women's illiteracy likewise 22\%:78\%, besides female economic dependency (C9) contributed the result like 10\%:90 and at the end 14\%:86\% respondents belong to C10 (see Table-3). 
Table-3: Cross Tabulation of Socio-Cultural Impediments and Women Education

\begin{tabular}{|c|l|c|c|c|}
\hline \multirow{2}{*}{ Categories } & Socio-Cultural Impediments & \multicolumn{2}{|c|}{ Women Education } & \multirow{2}{*}{ Total } \\
\cline { 3 - 4 } & & $\begin{array}{c}\text { To Lower } \\
\text { Extent }\end{array}$ & $\begin{array}{c}\text { To Greater } \\
\text { Extent }\end{array}$ & \\
\hline C1 & Patriarchy and male dominancy & $1(2 \%)$ & $52(98 \%)$ & $53(100 \%)$ \\
\hline C2 & Centuries old customs and traditions & $2(22 \%)$ & $7(78 \%)$ & $9(100 \%)$ \\
\hline C3 & Pakhtun codes & $4(25 \%)$ & $12(75 \%)$ & $16(100 \%)$ \\
\hline C4 & Gender bias social structure & $3(30 \%)$ & $7(70 \%)$ & $10(100 \%)$ \\
\hline C5 & Feudalism & $2(20 \%)$ & $8(80 \%)$ & $10(100 \%)$ \\
\hline C6 & Purdah system & $4(21 \%)$ & $15(79 \%)$ & $19(100 \%)$ \\
\hline C7 & Poverty & $4(18 \%)$ & $18(82 \%)$ & $22(100 \%)$ \\
\hline C8 & Unemployment & $2(22 \%)$ & $7(78 \%)$ & $9(100 \%)$ \\
\hline C9 & Women economic dependency & $1(10 \%)$ & $9(90 \%)$ & $10(100 \%)$ \\
\hline C10 & Illiteracy & $1(14 \%)$ & $6(86 \%)$ & $7(100 \%)$ \\
\hline CT & Total & $24(15 \%)$ & $141(85 \%)$ & $165(100 \%)$ \\
\hline
\end{tabular}

$\mathrm{P}=0.000^{* * *}<0.05$ and $\chi 2=32.969$

Consequently, the statistical interpretation expresses the relationship between independent and depended variables. This is stated in the hypothesis i.e., "Traditionalistic approach in Pakhtun society decreases women's education." The chi-square test is applied to test the hypothesis, the value of $\mathrm{P}=0.000^{* *}<0.05$ there is highly significant relationship between socio-cultural impediments and women education, $\chi 2=32.969$, D.F. $=9$ shows that the result is highly significant. Therefore, it is concluded that socio-cultural obstacle decreases women education. Further the correlation analysis authenticates the results and describes as *Correlation is only significant at the 0.01 level (2-tailed), $r(165)=0.856^{*} ; \mathrm{p}<0.01 . \mathrm{r}^{2}=0.73$, since $73 \%$ of the variance is shared, the association is obviously a strong one, which concludes that the sociocultural impediments are a threat to women education in Pakhtun society (see Table-4).

Table-4: Cross Tabulation of Women Education and Socio-Economic Impediments

\begin{tabular}{|l|l|c|c|}
\hline \multicolumn{2}{|l|}{ Statement } & $\begin{array}{c}\text { Women's } \\
\text { Education }\end{array}$ & $\begin{array}{c}\text { Socio-Economic } \\
\text { Impediments }\end{array}$ \\
\hline \multirow{3}{*}{ Women's Education } & Pearson Correlation & 1 & $0.856^{*}$ \\
\cline { 2 - 4 } & Sig. (2-tailed) & & 0.009 \\
\cline { 2 - 4 } & $\mathrm{N}$ & 165 & 165 \\
\hline \multirow{5}{*}{ Socio-Economic Impediments } & Pearson Correlation & $0.856^{*}$ & 1 \\
\cline { 2 - 4 } & Sig. (2-tailed) & 0.009 & 165 \\
\cline { 2 - 4 } & $\mathrm{N}$ & 165 & \\
\hline
\end{tabular}

${ }^{*}$ Correlation is only significant at the 0.01 level (2-tailed), $r(165)=.856^{*} ; \mathrm{p}<.01 . \mathrm{r}^{2}=0.73$, since $73 \%$ of the variance is shared, the association is obviously a strong one.

\subsection{Relation between Women Education and Human Capital Development}

The data shows a significant relation between women education and human capital development. The statistical analysis elucidate that the response of the respondents is recorded on two-point categories i.e. to low extent (TLE) and to greater extent (TGE) which is so as 94\%:6\%. The quantitative analysis further demonstrate, that women illiteracy decrease human 
capital likewise 0\%:100\%, similarly women education is closely associated with economic production, women illiteracy decrease production as 0\%:100\%, while GNP decrease 0\%:100\%, in the same women low level of education is correlated with GDP which is attributed 12\%:88\% accordingly. The above the statistical analysis further expound that economic stability contributed to women education as 9\%:91\%, beside illiteracy reduce per capita income as 8\%:92\%. Moreover, human development suffers like 9\%:91\%, whereas employment opportunities related to women education in way that 9\%:91\% (see Table-5).

Table-5: Cross Tabulation of Women Education and Human Capital Development

\begin{tabular}{|l|c|c|c|}
\hline \multirow{2}{*}{ Economic Development } & \multicolumn{2}{|c|}{ Women Education } & \multirow{2}{*}{ Total } \\
\cline { 2 - 3 } & To Lower Extent & To Greater Extent & $21(100 \%)$ \\
\hline Human capital & $0(0 \%)$ & $21(100 \%)$ & $20(100 \%)$ \\
\hline Production & $0(0 \%)$ & $20(100 \%)$ & $20(100 \%)$ \\
\hline GNP & $0(0 \%)$ & $20(100 \%)$ & $24(100 \%)$ \\
\hline Economic stability & $3(12 \%)$ & $21(88 \%)$ & $11(100 \%)$ \\
\hline Per capital income & $1(9 \%)$ & $10(91 \%)$ & $24(100 \%)$ \\
\hline Human development & $2(8 \%)$ & $22(92 \%)$ & $22(100 \%)$ \\
\hline Employment opportunities & $2(9 \%)$ & $20(91 \%)$ & $23(100 \%)$ \\
\hline Total & $2(9 \%)$ & $21(91 \%)$ & $165(100 \%)$ \\
\hline
\end{tabular}

$\mathrm{P}=0.000^{* * *}<0.05$ and $\chi 2=21.982$

The chi-square test and correlation techniques are used to check the validity of hypothesis. The result of chi-square proves that there is highly significant relationship among women education and human capital development $\left(\mathrm{p}=0.000^{* *}<0.05, \chi^{2}=21.982\right.$, D.F $\left.=9\right)$. The correlations further confirm the alliance of women education and human capital development in a compile numerical forms as *Correlation is only significant at the 0.01 level (2-tailed), $r(165)=0.842^{*}$; $\mathrm{p}<0.01 . \mathrm{r}^{2}=0.71$, since $71 \%$ of the variance is shared, the association is obviously a strong one. So, it has been concluded that the "hypothesis Gender inequality in education results in lower per capital income" is proved as authentic (see Table-6).

Table-6: Correlation of Women Education and Human Capital Development

\begin{tabular}{|l|l|c|c|}
\hline \multicolumn{2}{|c|}{} & Women's Education & Human Capital Development \\
\hline \multirow{4}{*}{ Women's Education } & Pearson Correlation & 1 & $0.162^{* *}$ \\
\cline { 2 - 4 } & Sig. (2-tailed) & & 0.004 \\
\cline { 2 - 4 } & $\mathrm{N}$ & 165 & 165 \\
\hline \multirow{3}{*}{$\begin{array}{l}\text { Human Capital } \\
\text { Development }\end{array}$} & Pearson Correlation & $0.162^{* *}$ & 1 \\
\cline { 2 - 4 } & Sig. (2-tailed) & 0.004 & 165 \\
\cline { 2 - 4 } & $\mathrm{N}$ & 165 & \\
\hline
\end{tabular}

* Correlation is only significant at the 0.01 level (2-tailed), $r(165)=0.842^{*} ; \mathrm{p}<0.01, \mathrm{r}^{2}=0.71$

\section{Conclusion}

This study concludes that although half of the population in the study area (i.e. village Chakdara, tehsil Chakdara) is constituted by women. However, the socio-cultural discourses of the area are strongly influencing gender inequality in education which subsequently affecting economic 
development in the aforementioned area. The socio-cultural circumstances of women i.e., domestic responsibilities, marital obligations, patriarchy, purdah system, feudal structure, and gender biased psychology of the people are the dominant factors behind the gender inequality in education. Besides, this gender inequality in the education sector i.e., ideologically penetrated gender biased text, unequal gender enrolment, gender priorities and social preference have affected economic development very badly. This discriminatory gender discourse in education is creating an imbalanced human capital among women and men. Intriguingly, feudalistic nature of the area and purdah system have key role in blocking the way of women's education. This study also concludes that due to cultural restrains women are not allowed to be involved in the economic affairs of the family. Due to gender inequality in education, the economic development is severely affected as per capita income and production are lowering down which has bad reflections in the GDP and GNP. Most importantly, due to unfair treatment with women in education they got a status as unpaid labour at the house chores which are not good for the improvement of overall economy in the area. The study recommends that the socio-cultural environment for women may be relaxed especially for their education. Moreover, an equality-based gender socialization and orientation may be adopted that both the genders may become potential for contributing to the economic development of the area.

\section{References}

Behrman, J. R., \& Deolalikar, A. (1988). Health and nutrition. In Handbook of Development Economic. Eds., Hollis Chenery and T. N. Srinivasan, Vol. 1, Amsterdam: North Holland Publishing Company.

Behrman, J. R., \& Wolfe, B. L. (1984). More evidence on nutrition demand: Income seems overrated and women's schooling underemphasized. Journal of Development Economics, 14(1), 105-128.

Behrman, J. (1997). Mother's schooling and child education: A survey. Unpublished manuscript. Philadelphia, PA: University of Pennsylvania.

Chaudhry, I. S., \& Rahman, S. (2009). Impact of gender inequality in education on economic growth: An empirical evidence from Pakistan. European Journal of Economic, Finance and Administrative Sciences, 15(1), 174-188.

Chaudhry, I. S. (2010). Poverty alleviation in Southern Punjab (Pakistan): An empirical evidence from the project area of Asian Development Bank. International Research Journal of Finance and Economics, 23. Retrieved from https://waseb.wordpress.com/2010/04/20/poverty-alleviation-in-southern-punjabpakistan-an-empirical-evidence-from-the-project-area-of-asian-development-bankby-imran-sharif-chaudhry/

Cohen, D., \& Soto, M. (2001). Growth and human capital: Good data, good result. Journal of Economic Growth, 12(1), 51-76.

Hannan, C. (2004). Director United Nations division for the advancement of women: Gender equality and women's empowerment in the new millennium. In Interfaith InstituteWomen: Her Spiritual Journey. Litchfield, CT: Wisdom House.

Jejeebhoy, S. (1995). Women's education autonomy and reproductive behaviour: Experience from developing countries. Oxford University Press.

King E. L., \& Hill, M.A. (1993). Women's education in development countries: Barriers, benefits, and policies. The World Bank.

King, E. L., \& Hill, M. A. (2001). Engendering development: Through gender equality in rights, resources, and voice. The World Bank 
Klasen, S. (2002), Low schooling for girls, slower growth for all? Cross-country evidence on the effect of gender inequality in education on economic development. The World Bank Economic Review, 16(3), 345-373.

Knowles, S., Lorgelly, P. K., \& Owen, P. D. (2002). Are educational gender gaps a brake on economic development? Some cross-country empirical evidence. Oxford Economic Papers, 54(1), 118-149.

Krueger, A. B., \& Lindahl, M. (2000). Education for growth: Why and for whom? National Bureau of Economic Research, Working Paper No. 7591. Retrieved from, https://www.nber.org/papers/w7591.pdf

Lagerlof, N. P. (2003). Gender equality and long-run growth. Journal of Economic Growth, 8(4), 403-426.

Mensch, B., Lentzner, H., \& Preston, S. (1985). Socio Economic Differentials in Child Mortality in Developing Countries. New York: United Nations.

Mishra, R. C. (2005). Women Education. New Delhi: A. P. H Publishing.

Montgomery, M. R., Arends-Kuenning, M., \& Mete, C. (2000). The Quantity-Quality Transition in Asia. In Population Change in Asia: Transition, Development, and Aging, edited by Cyrus Chu and Ronald Lee; a supplement to Population and Development Review, Vol. 26. Nussbaum, Martha.

Raynor, J., Wesson, K., \& Kyenes, M. (2006). The girl's stipend programs in Bangladesh. Journal of Education for international Development, 2(2), 1-12.

Sen, A. (1990). Gender and cooperative conflicts. In Persistent Inequalities, (ed.) by Irene Tinker. New York: Oxford University Press.

Schultz, T. P. (1993). Returns to women's education. In Women's education in developing countries: Barriers, benefits, and policies, by Elizabeth King and M. Anne Hill (Eds.). Baltimore, MD: The World Bank.

Schultz, T. P. (2002). Why governments should invest more educating. World Development 30(2), 207-225.

Schultz, T. P. (1997). Demand for children in low-income countries. In M. Rosenzweig and O. Stark (eds.). Handbook of Population and Family Economics. Amsterdam: North Holland Publishing Co.

Strauss, J., \& Thomas, D. (1995). Human resources: Empirical modelling of household and family decisions. In Handbook in Development Economics (Eds.) by Jere Behrman and T. N. Srinivasan, Vol. 3A, 1883-2023, Amsterdam: Elsevier.

Todaro, M. (1997). Economic Development (6 ${ }^{\text {th }}$ Ed.). Reading, Mass Addison-Wesley Publishing.

Ullah, K., Mustafa, J., \& Badshah, S. (2017). Gender-wise perception of graduate and undergraduate students about the quality of teaching. Liberal Arts \& Social Sciences International Journal (LASSIJ), 1(1), 10-19.

Yamarik, S., \& Ghosh, S. (2003). Is female education productive? A reassessment. Medford, MA: Tufts University. 